Paper published as:

2003 Salager Meyer, F., M.A. Alcaraz Ariza and N. Zambrano. "The scimitar, the dagger and the glove: intercultural differences in the rhetoric of criticism in Spanish, French and English medical discourse (1930 1995)" English for Specific Purposes. Vol. 22, p. 223 247.

\title{
The scimitar, the dagger and the glove: Intercultural differences in the rhetoric of criticism in Spanish, French and English Medical Discourse (1930-1995)
}

Françoise Salager-Meyer*, Escuela de Idiomas Modernos y Facultad de Medicina. Universidad de Los Andes. Mérida. Venezuela.

María Ángeles Alcaraz Ariza. Facultad de Filosofía y Letras. Departamento de Filología Inglesa. Universidad de Alicante. Alicante, Spain.

Nahirana Zambrano. Escuela de Idiomas Modernos. Universidad de Los Andes. Mérida. Venezuela.

"We should not fear diversity of views. On the contrary, progress in science demands it. The only way to frame the best answers possible in the face of incomplete knowledge is to allow differing views to be expressed" (Sniderman. The Lancet. 1999: 328)

\begin{abstract}
The socio-pragmatic phenomenon of academic conflict (AC) is here addressed from a cross-cultural and diachronic perspective, and is examined by combining a quantitative approach and a qualitative discoursal analysis of its salient rhetorical features in a corpus of Spanish, French and English medical articles published between 1930 and 1995. The speech acts that conveyed AC were recorded in each paper and classified into 2 categories according to their level of commitment (direct author's involvement) or detachment (hedginess and $\mathrm{AC}$ responsibility shifting). The quantitative results were analyzed by means of the Chi-square test. Our overall findings indicate that French and Spanish scientists tend to be not only more critical, but also more authoritarian and passionate in the formulation of their AC than their Anglo-Saxon counterparts. However, when analyzed diachronically, our results indicate that from the 1990 s on, the rhetorical behavior of
\end{abstract}

\footnotetext{
* Corresponding author. Mailing address: Apartado 715. Mérida. Venezuela. E-mail: fmeyer@ telcel.net.ve
} 
Spanish AC (though still somewhat blunt and personal) quite abruptly distinguishes itself from that of French and starts adopting the more veiled and "politically correct" tone of English AC. By contrast, the discursive pattern of French AC did not substantially change over time, although its indirectness slowly and continuously increased over the period studied. By placing the above results within their broader educational, political, historical and socio-economic context, it can be claimed that the behavioral changes observed in the framing of $\mathrm{AC}$ reflect the evolution of an increasingly promotional, competitive, professionalized, collegial and pragmatic end-of- $20^{\text {th }}$-century scientific research which tends to compel scientists to progressively change their vision of science, although certain cultures seem to be more vulnerable to external penetration than others.

Key words: medical English, French and Spanish; academic criticism; historical studies; contrastive rhetoric

\section{INTRODUCTION}

The great majority of cross cultural studies of academic rhetoric research has been directed towards comparing today's lingua franca of international communication with Oriental (mainly Japanese and Chinese), Scandinavian, Eastern European, Arabic and a few Western European languages, mostly German and French (see Connor 1996, chapter 3). It is only

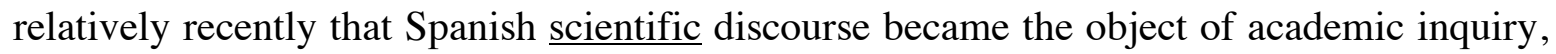
and it can safely be assumed that this is due to the fact that Spanish is today the third most frequently spoken language in the world, and that it shows signs of acquiring an increasing importance as a world trade, political, cultural and business (thus, international) language. ${ }^{1}$ The first scientific English/Spanish contrastive research compared the structure of medical

\footnotetext{
${ }^{1}$ It is estimated that by 2025 Spanish will be spoken in the United States of America alone by more than 40 million people (Segura 1998). Latin America produces the great majority of raw materials industrialized countries so badly need. The number of web sites in Spanish is increasing by the day. A few years ago, the CNN channel launched a 24-hour Spanish language network. Moreover, a recent analysis of the US census data by the National Council of La Raza (NCLR, 2001) shows that the growth of youthfulness of the Hispanic population will play a fundamental role in the social and economic future of the United States of America. All this means that the Spanish language will have an ever-increasing importance on the international arena. It is also interesting to note that a growing number of journals dedicated to research on languages for specific purposes and published in countries where Spanish is not spoken as a native language are accepting papers written in Spanish: e.g., Lebende Sprachen (Germany), Hermés and LSP and Professional Communication (Denmark), The ESPecialist and D.E.L.T.A. (Brasil). This policy, we believe, reflects the increasing importance of Spanish as an international language of communication and we contend that it should be followed by other leading journals in the field.
} 
article introductions (López 1982) and discussions (Vásquez 1987), and was later followed by lexical, syntactical and discoursal studies (Martínez 1994, Pak 1995, Moreno 1997 , Valero Garcés 1997, Espinoza 1997, Fortanet 1998 and Charteris-Black and Ennis 2001). In spite of that growing body of research, Fernández Polo (1995), Valero Garcés (1997) and Moreno (1997) claim that more English/Spanish comparative rhetoric studies on textrhetorical variables are needed. Their opinion is echoed by Johns and Swales (1998: 25) who in the late 90s noted with approval the surge of interest in contrastive rhetoric, but lamented at the same time the "unidirectional nature of that surge, whereby the target language is overwhelmingly English". They thus recommended that more attention be paid to languages other than English.

We hope that the study reported below will, at least in part, fill that gap and also contribute to a better understanding of the socio-pragmatic phenomenon of academic criticism (AC), a rhetorical variable that has recently attracted the attention of sociologists of science, linguists and applied linguists, especially those interested in academic discourse (Hunston 1993, Kourilova 1996, Hyland 2000, chapter 3, Salager-Meyer 2001), although, as Hyland (2000) observes, our knowledge of how criticism is expressed is very limited. Previous cross-linguistic research has referred to the frequency of critical speech acts in contemporary Asian and English scientific prose (Taylor and Chen 1991, Bloch and Chi 1995, among others) and in German, Polish and Czech academic writing (Duszak 1997). These studies point out that, unlike English, these languages tend to avoid focusing on previous research gaps and/or shortcomings and are low on text forms that express judgments of academic achievement and quality of previous research (for a review of the literature on AC, see Salager-Meyer 1999). By addressing the issue of AC from a combined cross-linguistic/cross-cultural and diachronic perspective, the present research works on the premise that many aspects of scientific texts can be accounted for in terms of the social and cultural context within which those texts are produced, and follows Bazerman's (1988) and Atkinson's (1996) recommendation to study scientific languages from a historical perspective in order to understand why regularities emerge, evolve and vanish and why particular features prove so useful to a given discourse community at a given point in time that they become institutionalized disciplinary practices (cf. Hyland 2000, especially Chapter 1). 


\section{PURPOSE}

First of all, it is important to mention that the present study draws on the results of previously published research on the evolution of AC in English (Salager-Meyer 1999), French (Zambrano 1999, Salager-Meyer and Zambrano 2001) and Spanish medical writing (Salager-Meyer and Alcaraz Ariza 2001, Alcaraz Ariza and Salager-Meyer 2001). The main purpose of this study is then to compare, over a 65 year-period (1930-1995) the quantitative and qualitative results obtained in the above research, i.e., to analyze and contrast the way native speakers of English, French and Spanish convey their professional disagreement over the period studied. A further aim of the present research is to relate the quantitative and qualitative cross-linguistic and diachronic variations observed to contextual factors. It is our contention indeed that there is a clear connection between a text and its context (Leech 1983, Valle 1999), i.e., that writers do not communicate in a vacuum, but are embedded in a constraining sociolinguistic setting from which they make the lexical, grammatical and rhetorical choices in order to indicate the purpose of their statements and their point of view (Régent 1994). The view of knowledge thus assumed in this paper (as something which is essentially constructed by texts) owes much to the work of the sociologists of science, especially to the so-called "weak form" of the socioconstructivist approach to discourse analysis according to which scientific knowledge is “contingent" (i.e., context-bound, Valle 1999: 11) and socially-constructed.

\section{LINGUISTIC CORPUS}

We analyzed 90 randomly chosen full length medical articles (30 in each language) published in medical journals between 1930 and 1995 (see Appendix for a list of the journals from which our sample texts were drawn). For the corpus to be representative of native English, French and Spanish scientific writing, the first author, at least, had to have an Anglo-Saxon, French and/or Spanish surname and be affiliated to an institution in 
countries where these languages are spoken as $\mathrm{L1}^{2}$. The articles published between 1930 and 1970 were selected on the basis of journal availability, whereas those published between 1970 and 1995 were chosen on the recommendation of two librarians and two specialists informants as well as on the Garfield's ranking listing of journals in the Journal Citation Report of the Science Citation Index (for further information on text selection, see Salager-Meyer and Zambrano (2001) and Alcaraz Ariza and Salager-Meyer (2001). The 90 articles selected totaled 218.113 running words (see their distribution per language in Table 1). In view of the fact that the corpus analyzed here yielded 366 instances of the variable under scrutiny (see Results section), we consider that it is large enough to reveal major trends. At any rate, as Conrad (1999: 17) makes clear, besides the information about largescale patterns in language use gained from corpus-based research that can analyze linguistic corpora of tens of hundreds of millions words, "we continue to need more intensive analyzes on smaller text samples."

The year 1930 was chosen as our starting point of analysis firstly because medical research (as it is conceived today, see 5.2.2. below) was almost non-existent in Spain before that date. Secondly, because the linguistic formulation of $19^{\text {th }}$ and early $20^{\text {th }}$ century academic criticism was found to be strikingly similar (acerbic, acrimonious, sometimes even offensive and downgrading) in the three languages under study (Salager-Meyer and Zambrano 2001, Salager-Meyer and Alcaraz Ariza 2001), and thirdly because the decade of the 1930s was found to act as a 'cut off' period in two respects: it is indeed from the 1930's on when, on the one hand, a rhetorical switch towards greater modulation was observed in English AC and when, on the other, English medical prose started differentiating itself from French medical writing regarding the ratio of direct/indirect AC (Zambrano 1999 and Salager-Meyer and Zambrano 2001).

\section{METHODS}

\footnotetext{
2 Although we are aware of the fact that first author' surname is no guarantee of native language background (North American native-English speakers with Spanish surnames, for instance), we think that the information about the institution where the first author works would maximize our chances to choose native English, French and Spanish-speaking scientists.
} 
The formal realizations of the speech acts which reflected a conflict between a scientist's knowledge claim ${ }^{3}$, on one side, and another scientist's knowledge claim (or an opinion upheld by an unidentified scientific community), on the other, were manually searched and recorded in each one of our 90 sample texts ${ }^{4}$. The AC thus recorded were divided into 2 broad categories according to their level of directness/indirectness:

a) Direct AC: a straightforward, overt criticism (i.e., an unmodulated assertion to which the writers fully commits themselves, taking full responsibility for thetruth of the propositional content of the utterance (ex. 1). ${ }^{5}$

1. Although no study has demonstrated a statistically significant overall seasonal variation in the incidence of this disease, the concept persists that exposure to cold is an initiating cause. (BMJ, 1974)

b) Indirect AC: a covert, polite, subdued criticism. The writer's commitment to the truth of the proposition is here is here modulated either through the use of hedging devices $^{6}$ (ex. 2) or through the rhetorical strategy that consists in shifting the responsibility of the AC away from the writer to some inanimate facts (e.g., a result, as in ex. 3)

2. Leibowitz's report of a significant clustering of cases appears to be based on an error in computation. (JAMA, 1974)

3. Our findings were unable to confirm those previously reported in the literature. (NEJM, 1990)

\footnotetext{
${ }^{3}$ A "knowledge claim" is generally understood as an item in a research article which scientists put forward to be added to the sum of the knowledge-bank agreed upon by the community of the discipline they belong to (Swales 1990). A "conflicting knowledge claim" is thus to be understood as a differential between knowledge claims (Hunston 1993).

${ }^{4}$ If, for example, the same criticism was directed at Smith (1956) several times in the same paper, it was recorded as one AC only. In cases when a critical comment was a reported AC -- i.e., when the AC is not expressed by the author of a paper him/herself (e.g., "Henschen suggested that Lowndown's use of anarthria was a source of confusion and should be abandoned"), the criticism was not recorded as an AC.

${ }^{5}$ All the examples provided in this paper are drawn from our sample texts, the year of publication of which is provided into brackets. In each example, the italicized words/expressions indicate the AC and the $(*)$ refers to a bibliographical reference mentioned in the original paper. Words/expressions written in bold indicate an indirect AC. For lack of space, only a few examples are provided here, but more examples and a detailed discussion of the quantitative and qualitative evolution of French and English AC can be found in SalagerMeyer and Zambrano (2001) and of Spanish in Alcaraz Ariza and Salager-Meyer (2001).

${ }^{6}$ Hedges have been interpreted, inter alia, as markers of politeness stance in which the mutual respect between researchers is exhibited in a desire not to impose one's belief on a peer (e.g., Hyland 1996), but they have also been viewed as rhetorical strategies used to protect the writer from criticism by leaving room for opposing points of view (e.g., Dong 1996).
} 
As a response to the subjective reading problem faced by all text-based research, and in order to increase the "construct validity and reliability" (Connor and Mauranen 1999: 50) of our study (i.e., to validate our own reading interpretation), we sought the cooperation of two subject-matter specialists (active researchers and fluent readers of English, Spanish and/or French medical prose), a practice highly recommended in all kinds of LSP-related discourse analysis (e.g., Selinker 1979, Valle 1999). We thus quite frequently held informal discussions with and sought, when necessary, the advice of these two medical researchers whose specialist insight into usage helped us correctly identify the AC and classify them per category (see above) whenever we had a doubt in that respect. Moreover, the project coordinator periodically reviewed the other researchers' progress of the work during frequent project meetings and e-mailed consultations.

The total number of $\mathrm{AC}$ was quantified in the three linguistic samples and results were normalized per 10.000 words. In order to appreciate the evolution of the variable under study, the 65 year-period examined was divided into 4 year-blocks (1930-1949, 1950-1969, 1970-1989 and 1990-1995), and the frequency of direct/indirect AC in each language and in each year-block was calculated. The data thus obtained were analyzed using non-parametric $\chi^{2}$ test for contingency tables. Alpha value was set up at $\mathrm{p}<.05$. Finally, in order to enhance the internal validity of the present study, the data were recorded and analyzed independently by our subject-specialists in a sample of 10 articles. Only slight discrepancies were found: interrater reliability was .83 .

We would finally like to mention that the method of analysis adopted here which combines the quantitative approach with qualitative studies and discourse analysis has lately been strongly recommended (e.g., Biber 1988 and 1999, Schiffrin 1994, Connor 1996, Conrad 1999) and is being used in an increasing number of recent LSP studies (e. g., Taavitsainen and Pahta 1998, Hyland 2001, Ferguson 2001).

\section{RESULTS AND DISCUSSION}




\subsection{Quantitative Results}

\section{1. 1. Overall frequency of academic conflicts in the three linguistic samples}

Table 1 displays the global results regarding the total number of AC (341) recorded in the English (77), French (120) and Spanish (144) corpora. The normalization of these results per 10.000 words shows that there are almost $12 \mathrm{AC}$ per 10,000 words in the English corpus, 17 in the French sample and 17.4 in the Spanish sample, a difference which (though not statistically significant) could allow us to speculate that French and Spanish-native speakers are more inclined to criticize their peers than their Anglo-Saxon counterparts are.

\section{1. 2. Cross linguistic comparison of the overall frequency of Direct AC}

Table 2 and Graph 1 display the percentages of direct and indirect AC observed in the 3 linguistic samples over the 65 years studied. They firstly clearly show that it is only in the English sample where the statistical test did not detect any significant difference between the frequency of direct (57.1\%) and indirect (42.8\%) AC. Secondly, they indicate that the direct AC recorded both in the Spanish (79.2\%) and the French (86.7\%) samples significantly outnumbers that observed in the English corpus $(57.1 \%): \mathrm{p}=.0001$ (Spanish $v s$. English) and $\mathrm{p}=.013$ (French $v s$. Spanish). By contrast, no significant difference was found between the frequency of direct AC recorded in Spanish and that recorded in French.

\section{1. 3. Cross-linguistic comparison of the overall frequency of Indirect AC}

Table 2 and Graph 1 also show that the indirect AC recorded in the English sample (42.8\%) is significantly greater than that observed in the French $(13.3 \%, \mathrm{p}=.001)$ and the Spanish $(20.8 \%, \mathrm{p}=.005)$ samples. Conversely, no significant difference was detected when comparing the frequency of the indirect $\mathrm{AC}$ recorded in the French sample with that observed in the Spanish corpus.

These quantitative results allow us to infer that, generally speaking and over the 65

years studied (considering that period as if it were a homogeneous block), Spanish- and French-speaking scientists have always been much more direct when expressing their professional disagreement than English-speaking scientists have. One would then almost be tempted to believe in the old saying according to which Latin people are more passionate than their Anglo-Saxon counterparts! 


\section{1. 4. Cross-linguistic comparison of the block-discriminated evolution of direct and indirect $A C$}

However, when analyzed diachronically (i. e., per year-block), our results highlight some interesting differences in the evolution of direct and indirect AC in English, French and Spanish medical discourse. Graphs 2 and 3 clearly illustrate that the evolutionary pattern of English AC quite conspicuously distinguishes itself from that of both French and Spanish AC. Indeed, in each year-block, direct AC were much less frequent in English than in French and Spanish. Consequently, in each year-block, indirect AC were much more frequent in English than in both French and Spanish medical literature.

Perhaps more interesting is the similarity in the evolutionary pattern of both direct and indirect AC in French and Spanish, at least up to the 1970-1995 year-Block. Indeed, over the first 3 year-blocks, the frequency of French and Spanish direct and indirect AC were not only very similar, but also remained constant (direct AC ranged between $82 \%$ and $89 \%$ in both languages, and indirect $\mathrm{AC}$ between $11 \%$ and almost 18\%). But, from the 1990s on, the pattern of Spanish AC quite strikingly starts differentiating itself from that of French AC to slowly resemble that of English AC. Indeed, in the last five years studied, Spanish direct AC exhibits a sharp (but not significant) decrease (from $87 \%$ to $70 \%$ ), whilst French direct AC keeps observing a slow descent (from $84 \%$ to $82 \%$ ). Moreover, it is only in this last 5 year-period when the frequency of Spanish direct AC (still higher, though, than that of English) was not found to statistically differ from that of English direct AC (70.6\% vs. $56.5 \%)$. On the other hand, in the last 5 years studied, Spanish indirect AC displays a sharp and significant increase (from 13\% to over 29\%), whereas French indirect $\mathrm{AC}$ continues its slow upward trend. Furthermore, it is only in this last 5 year-period when the frequency of Spanish indirect AC (still lower, though, than that of English) was not found to be statistically different from that of English indirect AC (29.3\% vs. $43.3 \%)$. In the closing years of the $20^{\text {th }}$ century, then, we can claim that French behaves like a "cavalier seul"! For how much longer?

\section{2. Qualitative Analysis}

\section{2.1. From a global perspective}


Our global (not block-discriminated) quantitative findings have clearly put forward that the overall frequency of direct AC over the 65 years studied is much greater in both French and Spanish than in English academic writing. This finding is in keeping with Motchane's (1990) and Régent's (1994) contention that French scientists are much more prescriptive, authoritative and categorical than their English-speaking colleagues who rather resort to "bémol ("flat") statements" (Régent 1994: 58). It is also in keeping with Martin (1996: 22) who contends that it is probably in the use of what he labels "précautions modales" (hedges) that lies the most prominent cultural difference between English and French academic prose. This led Beaufrère-Bertheux (1997: 232) to refer to the 'hypermodestie' of Anglo-Saxon scientists and Sionis (1997: 211) to the "exaggerated self-confidence of French academics" who therefore sound arrogant to their Anglo-Saxon counterparts ${ }^{7}$. In line with the above mentioned authors, but referring to speech, Béal (1994, quoted in Sionis 2000) points out that, when asking questions and making requests, French people often sound blunt or arrogant to Australian English speakers, whereas the French considered their Australian-English colleagues as 'wishy-washy', 'beating around the bush' and even hypocritical.'

Our overall finding is then in agreement with those of previous research (Bloor and Bloor 1991, Meyer 1997, Crosnier 1997, Beaufrère-Bertheux 1997 and Kreutz and Harres 1997) that has shown that hedging forms part of the system of conventions underlying academic writing, and that, "being conventional, it is bound to be culture-specific as well" (Vassileva 1997: 204). Research carried out in other languages has also shown that English academic writing is more heavily hedged than other languages such as Finnish (Ventola 1997, Duszak 1997) and Bulgarian (Vassileva 1997), and that hedges are more common in spoken English than in spoken German, while it seems to be the reverse in German/English academic writing (Clyne 1991). Hedging, then, is not favored by all cultures, and we can now add Spanish to the list of languages that shows a high degree of commitment and hence a lower degree of deference to the discourse community (the rhetorical switch towards the greater modulation of Spanish AC from the 1990s on is discussed in 5.2.2

\footnotetext{
${ }^{7}$ For the identification of modality as a problem area for NNES see, for example, Chersterman (1995) and Flowerdew (2001), and for a discussion of the pedagogical implications of the related lack of NNES sociopragmatic disciplinary competence in academic writing, see Connor (1996), Birch-Bécaas (1997), Allison et al. (1998) and Zambrano (1999), among others.
} 
below). Moreover, because hedging has been found to be of intrinsic significance to the interactional aspect of discourse (Kreutz and Harres 1997), we can thus state that both French and Spanish are much less interactional, i.e., less dialogic than English is.

We could relate the above mentioned greater modulation of English academic criticism (and greater authoritativeness of French and Spanish AC) to historically and culturally entrenched traditions that emphasize either an inductive-experimental or a deductive-theoretical approach in the search for truth. ${ }^{8}$ Indeed, as has already been argued (Galtung 1985), the Anglo-Saxon thought pattern has been greatly influenced by the inductive/experimental model - founded on skepticism, doubt and refutation (cf. Bacon 1561-1626; Hobbes 1588-1679; Locke 1632-1704 and Hume 1711-1776) - according to which the empirical pursuit for scientific "truth" is always relative and refutable. On the contrary, the French (and the German) have been much more influenced by the deductive/theoretical thought model (e.g., Descartes 1596-1650) which puts greater emphasis on theory formation and expresses itself in a more categorical way. The case of Spain is particularly interesting. Indeed, from the $18^{\text {th }}$ century till Franco's death in the mid70s, the influence of France in Spain in almost all matters (including, of course, its humanities/essay-type educational system) has always been much stronger than that of the Anglo-Saxon world. Spanish scientists used to go to France and Germany - two countries they considered as the world intellectual lighthouses - to receive their academic training. But the state of affairs swiftly changed with the arrival of a democratically-elected government in 1975 when a rapidly growing Spanish-speaking community began shifting its attention towards English-speaking countries ${ }^{9}$. The long-standing influence and impact

\footnotetext{
${ }^{8}$ A word of caution: this is not an exclusive 'either/or statement'. What we simply want to say here is that the deductive/theoretical thought model exerted a greater influence in southern than in northern European cultures. It is perhaps worthwhile reminding oneself at this point that it is in the mid- $19^{\text {th }}$ century when Auguste Comte categorically rejected the mutual tolerance that had existed for centuries between philosophy and religion, on the one hand, and experimental science on the other. The French sociologist indeed qualified religion as mere superstition and philosophy as a collection of lucubrations that could in no way lead to 'truth.' For Auguste Comte and other French scientists, 'truth' could only be reached through rigorous observation and experimentation. Most medical publications at that time, however, were based on the virtual witnessing of a few cases by 'experiencing-gentlemen scientists' (empirical, experience-based medicine) more than on rigorously carried out scientific experiments, and their authors were more inclined to deal with the art of healing than with community-generated research problems.
}

${ }^{9}$ We could perhaps talk of a "liberalization" of Spain during Franco's regime, but it was only a superficial one, characteristic of fierce dictatorships once they have reached absolute and indisputable power. 
of France and Germany with their strong emphasis on language arts and humanities could then, at least in part, account for the similarity observed between the French and the Spanish 'mudslinging' rhetoric over almost the whole year-period studied..$^{10}$

However interesting these considerations may be, we should not loose sight of the fact that our research has put forth important differences in the evolution of the frequency of English, French and Spanish direct and indirect AC. This is why we will focus our attention in the remainder of this paper on the analysis of the qualitative/rhetorical evolution of the framing of direct and indirect $\mathrm{AC}$ from a contrastive linguistic standpoint and relate the variations observed to the socio-historical context surrounding medical discourse production over the 65 years studied.

\section{2. 1. Direct AC}

Several rhetorical features quite clearly distinguish English from French and Spanish direct AC. Indeed, the direct AC recorded in our English sample articles (see footnote 4) reveal a rather gentle, neutral, dispassionate, matter-of-fact and apparently indifferent tone where the utterer of the $\mathrm{AC}$ tends to remain in the background, e.g.:

4. One is too prone to diagnose visceroptosis as the cause of the associated constipation... The purpose of this massage is to stimulate peristalsis. It is questionable if it accomplishes this, and undoubtedly, the intake of food forms a much more reliable stimulant. (BMJ, 1938)

5. Uncontrolled studies of continuous positive airway pressure (**) are also unreliable. (JAMA, 1960)

6. However, most of the studies previously carried out (**) have considered leukemia without discussing the immunological heterogeneity of differentiating stages of the disease. (L,1995)

\footnotetext{
${ }^{10}$ Folman and Sarig (1990) claim that rhetorical differences do not lie so much within the realm of different thought patterns, but more within the realm of the professed and implanted syllabi of language arts. It should be borne in mind, though, that these syllabi are a cultural product, i.e., a reflexion of a nation's particular thought patterns. In that respect, it is most interesting to note that Linneberg (1988: 33) explains the similarities between Finnish/Finland-Swedish and German discourse patterns in terms of "academic learning traditions in Finland that have to a great extent been influenced by German academic traditions". Vassileva (2001: 100), for her part, remarks that "the essay-like overall composition of Bulgarian academic texts is due to the long-standing impact of French and Russian, Russian itself being influenced by French", and Yakhontova (2001) emphasizes the fact that the Ukranian system of higher education still underwrites the highly theoretical stance characteristic of European (German and French) intellectualism.
} 
It is interesting to note that the politics of civility in English academic writing seems to have emerged in the post World War I period. As Liskin-Gasparro (2001) reports, sarcasm and negativity were apparently enough of an issue in the book reviews published in the Modern Language Journal throughout the 1920s and into the 1930s that Henry Grattan Doyle, then editor of the Journal, referred to it in at least two editorials (Doyle 1934 and 1938 cited in Liskin-Gasparro 2001: 79). As early as in 1934, then, Doyle urged book reviewers to express their "honest difference of opinion" in a courteous manner, without acrimony "and in language that preserves the amenities that ought to prevail among colleagues." (Doyle 1934: 34)

It is also of interest to point out that it is in the 1930's when English scientific style manuals started being published in the fields of experimental psychology and sociology. Political science, remarks Bazerman (1988), followed suit in the 1950s. We can safely assume that the publication of these style manuals is related to the long-standing tradition of the formal teaching of all types of writing in the American (and, to a lesser extent, British) educational system which saw in the 1940s a "mushrooming of general educational courses with emphasis on communication skills” (Connor 1996: 60) ${ }^{11}$. By contrast, such teaching has never been a tradition either in Scandinavian countries (Andersson and Gunnarson 1995), Eastern or Western Europe (Ventola 1997, Cmejrková and Danes 1997, Vassileva 2001, Yakhontova 2001, and Birch-Bécaas, Dumont, Pastore and Sionis's personal e-mailed communications), Hong Kong, China and Taiwan (Braine 2001) or Latin America. In these countries, writing skills are not taught as separate courses in any field and at any educational level, because students are expected to have mastered these basic skills in secondary schools. Science students and researchers, then, 'simply' learn how to write academic papers through the 'self-teaching sink or swim' practice of “intertextuality" (Williams 1992: 182), i.e., through extensive reading (St. John 1987, Parkhurst 1990, Shaw 1991, Guyon and Guyon 1996, Yakhontova 2001, among many others) or by writing more to proceed in their scientific careers (Connor 1996, Olsen 1999).

\footnotetext{
11 It is in 1873 when Harvard University added an English composition requirement to its list of admission standards. As Connor (1996, chapter 4) interestingly points out, numerous journals in the United States (more than anywhere else in the world) are entirely devoted to the research and teaching of writing, today a respectable object of academic inquiry.
} 
It is only very recently that style manuals to write academic papers in the scientists' native language have made their appearance in Ukraine, France, Spain and Latin America (see 5.2.2. below). It seems, however, that this frenzy has not yet reached either Finland or Czechoslovakia (cf. Vassileva 2001), but it soon will, for it is very good business, as is the very recent introduction of extra-curricular (i.e, not institutionalized) scientific Spanish writing courses in a few Latin American countries.

To come back to the tone of direct AC in English, French and Spanish medical writing, we would like to underline the fact that the neutral and rather depersonalized (i.e., object-centered) framing of English direct AC illustrated in ex. 4 to 6 above stands in sharp contrast with the vigorous, often times passionate, acerbic, author-centered and frequently scathingly sarcastic tone of French (ex. 7 to 9 below) and Spanish (ex. 10 to 12) direct AC:

\section{French}

7. Je serais plus sûr de ces résultats statistiquement parlant si le nombre de cas présentés par JL Faure était plus considérable et si le 5.5\% de mortalité opératoire que la statistique inflige à JL Faure ne reposait pas sur une seule mort.... Si le Professeur Hartman attachait plus d'importance à la statistique, il n'aurait pas tendance à revenir à sa colpo-hystérectomie. (AMI,1933)

8. Il est donc abusif d'appliquer le terme de dépistage à la recherche optique de Bernard Kleinman. ... De tels rapprochements avec l'examen radiologique systématique ne sont fondés ni dans les mots ni dans les faits. (ANM, 1969)

9. Si les premiers résultats obtenus grâce aux paradigmes classiques d'attention se sont montrés à la hauteur des espoirs envisagés en gérontologie, malheureusement peu de ces équipes de recherche (Plude 1990, Madden 1990) ont écarté les explications en termes de diminution des ressources d'attention. (AIP, 1995)

\section{Spanish}

10. Fue, ciertamente, un mal momento en la historia de la Neurología aquel día de 1869 en el que, en la "British Association for the Advancement of Science" se enfrentaron Jackson y Broca y éste quedó victorioso. Con ello se retrasó en sesenta años el adecuado enfoque de las localizaciones cerebrales. El dislate lógico que los seguidores de Broca y este mismo cometían, era tremendo. (AMI, 1946)

11. Insistimos en la necesidad del diagnóstico del prolapso, pero debemos advertir que la novedad de su hallazgo y la satisfacción de encontrarse con típicas imágenes no bastan para que tan alegre como inconscientemente se olvide del examen detallado del estómago y del duodeno, ya que en éstos pueden existir o desarrollarse 
inadvertidamente en el futuro graves procesos orgánicos que ocasionen serias complicaciones o que afecten incluso a la vida del paciente. (RCE, 1966)

12. Esta proliferación de presuntas aplicaciones de la vitamina $C$, unida a los sonados fracasos en la demostración de eficiencia clínicamente relevante en el resfriado común (*) y en el cáncer avanzado (*) han contribuido no poco a su discrédito (lo que sirve para casi todo, habitualmente no sirve para nada). (AFMM, 1993)

We could finally add that, apart from their withering sarcasm and acrimonious tone even more conspicuous in Spanish than in French (in fact, example 12 practically drips with sarcasm), examples 7 to 12 clearly bear evidence of a strong author's involvement that is linguistically realized through the frequent use of first personal pronouns and emotionallycharged booster expressions of stance.

\subsubsection{Indirect AC}

Over the 65 years studied, the indirectness and covertness of AC was equally textualized in the three languages either through the use of traditional "sugar coating" (Wilss 1997: 144) hedging elements or by means of the rhetorical strategy that consists in attributing the responsibility of the AC to a "talking fact" (Meyer 1997: 21) rather than to the researchers themselves who then become self-effaced and apparently 'humble' (cf. Hyland 2001) behind-the-scene supporting actors (ex. 13 to 18 below). It should be noted, however, that the latter strategy is more frequent not only in English than in French and/or Spanish, but also in papers published in the late $20^{\text {th }}$ century than in those published in the mid $20^{\text {th }}$ century. Regarding the overall tone of indirect AC, examples 13 to 18 below clearly illustrate that, in spite of their modulation, French and Spanish indirect AC are much blunter- sometimes with a slight touch of irony (ex. 16) -- than English indirect AC:

\section{English}

13.Their conclusions may be debatable. (JAMA, 1963)

14. Anecdotal evidence from clinicians indicates that some patients obtain dramatic benefit from treatment. Our study, however, suggests that health care intervention is less effective than anticipated. (BMJ, 1994) 


\section{French}

15. Prescrire les sulfamides à titre de préventif contre la grippe nous apparaît $a u$ premier chef un manque de sens critique. De même, il faut juger discutable l'emploi de cette forme de traitement. (AIP, 1938)

16. La divergence entre nos résultats et ceux des auteurs japonais est telle que l'on pourrait se demander s'il s'agit bien de la même maladie. (AMI, 1982)

\section{Spanish}

17. OERI encuentra 62 a 97\%, cosa que parece un poco exagerada a nuestro juicio, predominando los desplazamientos hacia la izquierda. (MC, 1941)

18. Así, nuestros resultados no confirman la opinión de que la aparición de la neuropatía diabética no se relaciona exclusivamente con la edad del paciente, sino tambíen con la duración de la enfermedad. (RCE, 1994)

We could speculate that the greater use of such conflict- or impact-attenuating rhetorical strategies in Anglo-Saxon academic prose rests upon the greater pressure -- referred to as "fierce competitiveness" (Duszak 1997: 32) or "academic struggle" (Cmejrková and Danes 1997: 52)-- imposed upon the members of the Anglo-Saxon academia. The "publish or perish" syndrome -- which requires a non-committal, collegial and "inoffensive" formulation of professional conflict-- is certainly slowly reaching all scientists worldwide (Hyland 2000), but not at the same rate as it is in English-speaking-countries. As Duszak (1997: 32) argues: "An academic (English) text becomes more of a marketable product that must make its way in order to get on the market", and this, she explains, can be accounted for the influence that social structure relations and general systems of values have on how knowledge is presented and how academic solidarity and competition are envisaged. Along the same line of thought, Berkenkotter and Huckin (1995: 43) remark that the need of today's Anglo-Saxon scientists to promote their work "to a degree never seen before" is a response to the increased competitiveness of modern Anglo-Saxon science which is itself embedded within a promotional, consumer post-industrial culture. ${ }^{12}$

\footnotetext{
${ }^{12}$ We could say that the greater modulation of Anglo-Saxon academic conflict from the 1930's is the result of a "multi-factored game" where the protagonist is the concept of competitiveness (a characteristic feature of post-modernity): 1) the number of journals tremendously increased in the last 20 years or so; 2 ) these journals
} 
Now, as we said before (see 5.1.4), a most interesting finding of our study is that related to the significant increase in Spanish indirect AC observed from the 1990's on which indicates its tendency to be framed more according to the Anglo-Saxon than to the French model. Several socio-historical factors can explain such a rhetorical switch. We would firstly like to allude to the political and socio-economical context of Spain during Franco's dictatorship, and to the changes that happened following his death in 1975. After World War II, the United States of America started exerting a strong influence in Europe in almost all matters, but, because of Franco's dictatorship, that influence has been much less strongly felt in Spain than in the other Western European nations. It is only after Franco's demise (and with the arrival of a democratic government) that Spain, till then left behind, was able to "board the train" of modernity and so-called "progress and development", and to open up to its European neighbors. Spain becomes a NATO member in 1985; it enters the Common Market in 1986 and is no longer the back wagon of Europe. The derogatory metaphorical slogan "Europe starts at the Pyrénées" then ceases to apply. The fact that Spain became a member of a union of democratic, "developed" countries favored not only access to education in general, but also to an increasing contact with Anglo-Saxon scientific circles $^{13}$ (i. e., to a pragmatic, techno-scientific and competitive culture). All this engendered a greater competition among the members of the Spanish research community who all yearn to join in the great game of science by engaging in disciplinary forums, and to belong, through their publications, to the international (i.e., English-speaking) scientific community, the best way for them to become visible, gain credibility and membership and receive reward of recognition which is frequently accompanied by material advantages ${ }^{14}$.

compete among themselves; 3 ) their editors and financing bodies require humility when advancing claims; and 4) scientists and universities feel the urge to reach high marks in an academic world obsessed by numbers and its related cult for scientometry.

${ }^{13}$ In Latin America and Spain, today's researchers -especially those working in the engineering, science and natural science faculties -- hardly ever consult sources written in Spanish (much less in French) for their research and teaching purposes. It is a fact that Spanish and Latin American medical, business and economic education (for the case of Spain, see Moreno 1997) is today strongly influenced by English-speaking academia. Indeed, the great majority of undergraduate and graduate-level texts in these three fields are materials translated from English (and, unfortunately, frequently poorly translated) into Spanish (see footnote 14).

${ }^{14}$ Latin American and Spanish scientists usually seek to publish what they consider their best works in international English-written journals which reach a wide audience, whereas they submit their "lower category" manuscripts to Spanish-written journals (see Flowerdew 2001 for a report of how the editors of English-written scientific periodicals view the issue of non-native English speaking). Lately, a similar trend 
More funds are then dedicated to research and development, but, as we all know, research funds are always too scarce. Under such circumstances, arrogance, sarcasm and acerbic criticisms are certainly not good allies!

The "in-between" stance of French academia could be accounted for by the fact that France is perhaps, of all the European countries, the one that most obstinately clung to its traditions (cultural legacy) by attempting, inter alia, not to succumb to the above mentioned 'wreck of subjectivity', and to fiercely resist the Anglo-Saxon cultural penetration (the 'love-hate' relationship between France and the U.S.A is now a cliché!). We could speculate, then, that France's position (coupled with the influence of the deductive/theoretical way of thinking which we referred to above) exerted a strong effect on the way French-speaking scientists have been conveying their dissension over time. Nonetheless, in view of the fact that our study has brought to the fore that French AC seems to be slowly adopting a slightly more modulated tone, we could wonder whether this means that the well-established standards of expressing a conflicting stance (so deeply ingrained, it seemed, in French speakers' cognitive schemata) are not slowly foundering under the influence of foreign thought-patterns.

But there is another factor, we believe, that is lately having an effect on the way today's Spanish-speaking scientists convey their criticisms. As we said before, it is only in the early 1990s when style manuals to write academic papers in Spanish started making their appearance on the Spanish-speaking market. It is firstly worthwhile mentioning that the deficient writing skills of Spanish scientists is quite frequently put to the fore in these manuals, and that the pernicious de-emphasis on language arts syllabi of the last few years is held accountable for such a deficiency (Caldeiro et al. 1993) ${ }^{15}$. It is also very interesting to note, on the one hand, that some of these style manuals are translations into Spanish of manuals originally written in English (e.g., Day 1996), and, on the other, that most references mentioned in these texts are English-written sources (e. g., Caldeiro et al. 1993,

can also be observed in the Ukranian-speaking academia (Yakhontova 2001) and, though to a lesser extent, within the French-speaking scientific community.

${ }^{15}$ Caldeiro's et al. verbatim quote is: “... otra cosa que contribuye al mal uso del castellano es su deficiente conocimiento y la falta de formación y práctica del ejercicio de la escritura, como resultado de una nefasta omisión de estos aspectos en nuestra educación básica de hace unos años." (Caldeiro et al. 1993: 139). (The underlining is ours). 
Martín Vivaldi 2000). Spanish-speaking scientists are then unsurprisingly urged to use a courteous, polite and respectful tone when dissenting with their peers and to "de-focus" the agents involved in the communication act (researchers and readers) in order to "... more clearly and precisely focus on the message, on the information that is being transmitted"16 (Montolío et al 2000: 163). This is what we referred to earlier (5.2 .2) as the 'responsibility shifting' strategy. So, not only are Spanish-speaking scientists more and more in contact (mainly through reading and, to a lesser extent, through writing and attending conferences) with the Anglo-Saxon scientific world, but they are also given stylistic and rhetorical recommendations to write academic papers in their own native language which follow and imitate the norms characteristic of a foreign culture. It is as though Spanish-speaking scientists did not have enough "time" to develop their own scientific culture, because Spanish science (that had traditionally been a "magister dixit", viz., authoritative science) made too swift a jump in the last 2 or 3 decades of the $20^{\text {th }}$ century to join in the breathtaking ascent of evidence-based techno-science. Spanish researchers thus saw themselves in a situation where they had to adopt the discursive patterns or "tribal lore" (Hyland 2000: 13) of that prevailing techno-scientific culture. Isn't that a clear example of academic acculturation and excessive standardization that "counteracts innovation and creative thought" (Mauranen 1993: 172), and that will in all likelihood give a strong impetus to the already existing rhetorical monopoly and monoculture against which, as Swales (2000: 67) so adroitly asserts, “ we need to consider offering 'cultural rainforest' arguments"?

The above historico-social considerations then lead us to argue that the greater deference and social solidarity towards the discourse community recently noted in medical papers written in Spanish by Spanish-speaking scientists rests on the following combination of intimately related factors: a) a transfer from L2 to L1 that can be accounted for by the scientists' extensive reading of English-written medical literature, b) the presence on the market of an increasing number of style manuals that are mostly based on the consultation of English-language sources and, last but not least, c) the very recent introduction of

\footnotetext{
16 The translation is ours. The original statement in Spanish is: “ ...lo más adecuado es evitar que los textos señalen hacia el escritor o hacia el lector, es decir, lo conveniente es desfocalizar la atención de las personas implicadas en la comunicación a fin de enfocar con más claridad y precisión el mensaje, la información que hay que transmitir."
} 
medical English writing courses at a few Spanish universities (e.g., Universidad de La Laguna, The Canary Islands $)^{17}$. These courses will very likely become more and more popular, thus giving a further boost to the L2 to L1 above mentioned transfer. It is interesting to note in that respect that previous studies offer convincing evidence of a lexical and syntactical transfer (to which we can now add a rhetorical transfer) from medical English into medical Spanish (Navarro 1998, Congost Maestre 1994, Alcaraz Ariza 2000), as if Spanish-speaking medical researchers were translating into Spanish the knowledge they had acquired from English-language sources, while also retaining the preferred rhetorical pattern of English. Less categorically, but still pointing to the possible presence of such a 'backward transfer', Moreno (1997) suggests that the similarities she observed in the use of causal metatext in Spanish and English research articles could be the result of the influence of Anglo-Saxon academic style on Spanish academic prose. It is finally worthwhile mentioning here that a scientific L2 to scientific L1 rhetorical transference has also been reported from Latin scientific writing into English medical writing in the Middle Ages (Taatvitsainen and Pahta 1998) ${ }^{18}$, from English to Japanese (Kubota1992) and Korean academic prose (Eggington (1987), and from the explicit and logical structure of the Western (Anglo-Saxon) style of academic writing on academic writing in Ukranian (Yakhontova 2001).

To conclude this rather long (but, we believe, necessary) discussion, we would like to argue, then, that the growing professionalization of research communities and the increased pragmatization, 'objectivization' and promotional competitiveness of end-of- $20^{\text {th }}$ century research tend to compel scientists to progressively (consciously or unconsciously) change their vision of science, precisely because the concept that prevails today is that of an increasingly competitive, productive, utilitarian, and technology- and evidence-based science.

\footnotetext{
${ }^{17}$ Since 1992, medical English courses (which include a writing component) are being offered at a few French medical schools as well (e.g., Lyon, Nantes, Dijon, Bordeaux).

${ }^{18}$ The dominant role of Latin in learned medical writing lasted in England till the middle of the $17^{\text {th }}$ century. Before that time, Latin prevailed, but, as Taavitsainen and Pahta (1998: 157) report, 207 of the 238 medical works published between 1640 and 1660 were written in English.
} 


\section{CONCLUSION}

Our results on the study of one rhetorical aspect of texts (the quantitative and qualitative analysis of academic criticism in three writing cultures of the Western world) thus lend further support to the argument that academic discourse strongly depends upon the milieu and the period in which it develops, that research reporting is culture/language bound, and that courtesy markers, solidarity and tactfulness are cultural manifestations. They are also consistent with the claim that it is not only highly different cultures which vary in their discourse preferences, but also those cultures which have had frequent contacts, whose languages are relatively similar to one another (Valero-Garcés 1997) and whose cultures are intimately related. Our research also supports the claim that social context always impinges on the discourses of the academy, and that all writing is strongly anchored in the values of the writing cultures that people get socialized into when they learn how to write, values that are inculcated and transmitted through national educational systems (Mauranen 1992, 1993). But, as we hope it has been made clear by our study, these educational systems are neither static not immutable but $\underline{\text { dynamic, }}$ in the sense that they may receive influence from other educational systems or intrinsic factors which will sooner or later modify a nation's cultural features and productive activities, thereby altering peoples' vision of the world and, consequently, the way they approach, inter alia, scientific "truth."19

Previous research (Mauranen 1993) has also rightly assumed that two sets of values are simultaneously at work in the writing of a scientific report: those common to the academic community and those held in esteem in the writer's national culture. "Both sets of values can be expected to leave their traces on texts", writes Anna Mauranen (1993: 239). In that respect, our research suggests that in the Spanish academic prose of the closing years of the $20^{\text {th }}$ century, the values favored by the international scientific community seem to have overcome those traditionally held in esteem by the writer's national culture,

\footnotetext{
${ }^{19}$ Up to the mid-1950s, the Latin American educational system was based on the French model. In most subject-matters, French textbooks (either in their original or in translated versions) were used in secondary schools, and the end-of-high-school exam was very similar to the French comprehensive essay-type baccalauréat. Moreover, at the tertiary education level, medical students mainly consulted French-language sources. But in the late $50 \mathrm{~s}$, the American educational system was adopted, and today's end-of-secondary school examination is very similar to the American multiple-choice-question Scholastic Aptitude Test (SAT). (cf. footnote 9).
} 
whereas it appears to be the reverse in French academic discourse where scientists till tend to consider themselves as unerring 'détenteurs du savoir' (Régent 1994: 84). In other words, national academic styles -- which can be traced back to different attitudes towards knowledge and learning (Clyne 1991) and to different epistemological traditions-- are certainly deeply embedded in cultural and rhetorical assumptions about how to present and organize knowledge in a maximally acceptable way, but they are also quite vulnerable to external social, cultural and political influences. The impact of wider societal and ideological trends and the political dimension underlying academic practices should thus not be overlooked, because they may constitute important sources of change (see Hyland 2000, Chapter 8). The Spanish-speaking academic community seems to be a case in point, and we could wonder how much longer the non-English speaking academia will be able to 'resist' the uniformization and standardization of, inter alia, scientific writing style dictated by the world globalization. Isn't already too late to prevent scientific discourse from becoming a monoculture which encourages conformity to approved disciplinary discursive practices, and may thus be considered as a system of increasingly restrictive social control?

Acknowledgments: This research was supported by Grant M-657-99 from the University of the Andes Research Center (Consejo de Desarrollo Humanístico, Científico y Tecnológico), Grant S1-98003578 from the National Research Center (Consejo Nacional de Investigaciones Científicas y Tecnológicas) and Grant POST00-09-80 from the Generalitat Valenciana (Valencia, España). We would finally like to thank Dr. Abdel Fuenmayor and Dr. Justo Hernández for their valuable advice as specialist informants.

\section{BIBLIOGRAPHICAL REFERENCES}

Alcaraz Ariza, M.A. (2000) Anglicismos en el Lenguaje de las Ciencias de la Salud. Alicante: Ediciones de la Universidad de Alicante.

Alcaraz Ariza, M.A., and Salager-Meyer, F. (2001) La disensión (¿velada o directa?) en la prosa médica española (1930-1999) Lebende Sprachen. In press.

Allison, D., L. Cooley, J. Lewkowicz and D. Nunan (1998) Dissertation writing in action: development of a dissertation writing support program for ESL graduate research students. English for Specific Purposes. 17(2), 199-217.

Andersson, B., and B.L. Gunnarsson (1995) A contrastive study of text patterns in conference abstracts. In Wårvick, B., S.K. Tanskanen and R. Hiltunen (Eds) 
Organization in Discourse. Proceedings from the Türkï Conference. (p. 139-148). University of Türkü. Anglicana Türküensia. Finland.

Atkinson, D. (1996) The Philosophical Transactions of the Royal Society of London, 1675-1975: a socio-historical discourse analysis. Language and Society, 25. 333371.

Bacon, F. (1605) Advancement of Learning. Classic Club. Walter J. Black. New York.

Bazerman, C. (1988) Shaping Written Knowledge. The Genre and Activity of the Experimental Article in Science. Madison: The University of Wisconsin Press.

Béal, C. (1994) Keeping the peace: a cross-cultural comparison of questions and requests in Australian English and French. In A. Pauwels (Ed.) Cross-Cultural Communication in the Professions. Special issue Multilingua. Vol. 13: 1/2. Berlin and New York. Mouton de Gruyter. p. 35-58.

Beaufrère-Bertheux, C. (1997): L'anglais de la recherche médicale: une grande diversité. ASp (Anglais de Spécialité): 223-238.

Berkenkotter, C., and T. Huckin (1995) Genre Knowledge in Disciplinary Communication. Hillsdale. NJ. Erlbaum.

Biber, D. (1988) Variation Across Speech and Writing. Cambridge: Cambridge University Press.

(1999) A register perspective on grammar and discourse: variability in the form and use of English complement clauses. Discourse Studies. 1(2), 131-151.

Birch-Bécaas, S. (1997). From author to reviewer to editor: negotiating the claim in a scientific article. A study of French researchers publishing in English? ASp (Anglais de Spécialité). No 3. 57-65.

Bloch, J., and L. Chi (1995) A comparison of the use of citations in Chinese and English academic discourse. In D. Belcher and G. Braine (Eds.) Academic Writing in a Second Language.( p. 231-277). Ablex Publishing Corporation. Norwood, N. J.

Bloor, M., and T. Bloor (1991) Cultural expectations and socio-pragmatic failure in academic writing. In P. Adams, B. Heaton and P. Howarth. Socio-Cultural Issues in English for Academic Purposes (p. 1-12) London. Macmillan Publishers Ltd.

Braine, G. (2001) When professors don't cooperate: a critical perspective on EAP research. English for Specific Purposes. 20(3), 293-303. 
Caldeiro, M. A., Feliu, E., Foz, M., Gracia, D., Herranz, G., Lience, E., Pulido, M., Ribera, J.M., Rey-Joly, C., F.J. and O. Vilaroya (1993) Manual de Estilo. Publicaciones Biomédicas. Barcelona: Moyby/Dosma Libros.

Charteris-Black, J., and T. Ennis (2001) A comparative study of metaphor in Spanish and English financial reporting. English for Specific Purposes. 20(3), 249-266.

Chesterman, A. (1995) Norm-breaking in academic discourse. In Wårvick, B., S.K. Tanskanen and R. Hiltunen (Eds.). Organization in Discourse. Proceedings from the Türkü Conference. (p. 201-212) University of Türkü. Anglicana Türküensia. Finland.

Clyne, M. (1991) The socio-cultural dimension: the dilemma of the German speaking scholar. In H. Schröder (Ed.) Subject-Oriented Texts. (p. 49-67). Berlin: Mouton de Gruyter

Cmejrková, S., and F. Danes (1997) Academic writing and cultural identity: the case of Czech academic writing. In A. Duszak (Ed.) Culture and Styles of Academic Discourse. (p. 41-63). Mouton de Gruyter: Berlin.

Congost-Maestre, N. (1994): Problemas de la traducción técnica: los textos médicos en inglés. Alicante: Publicaciones de la Universidad de Alicante.

Connor, U. (1996): Contrastive Rhetoric. Cambridge: C.U.P.

Connor, U., and A. Mauranen (1999) Linguistic analysis of grant proposals: European Union research grants. English for Specific Purposes_18(1), 47-62.

Conrad, S.M. (1999) The importance of corpus-based research for language teachers. System. 27 (1), 1-18.

Crosnier, E. (1997) Français vs. Anglais: histoire d'une rencontre avec pénalty ... et sans retour. ASp (Anglais de Spécialité) Vol.15-18. p. 55-77.

Day, A. (1996) Cómo Escribir y Publicar Trabajos Científicos. $2^{\circ}$ Edición en español. Traducción de M. Sáez. Washington. Organización Panamericana de la Salud.

Descartes, R. (1644) Principia Philosophiae. Amsterdam.

Dong, Y. (1996) Learning how to use citations for knowledge transformation: non-native doctoral students' dissertation writing in science. Research in the Teaching of English. 30, 428-457.

Doyle, H.G. (1934) Editorial. Modern Language Journal. 19, 34-35. 
(1938) How Modern Language reviews are handled. Modern Language Journal. 22, 379-380.

Duszak, A. (Ed.) (1997). Culture and Styles in Academic Discourse. Mouton de Gruyter.

Eggington, W.G. (1987) Written academic discourse in Korean: implications for effective communication. In U. Connor and R. Kaplan (Eds.) Writing Across Languages: Analysis of L2 Texts. (p. 153-168).

Espinoza, A.M. (1997) Contrastive analysis of the Spanish and English passive voice in scientific prose. English for Specific Purposes. 16(3), 229-244.

Ferguson, G. (2001) If you pop over there: a corpus-based study of conditionals in medical discourse. English for Specific Purposes. 20(1), 61-82.

Fernández Polo, J. (1995) Some discoursal aspects in the translation of popular science texts from English into Spanish. In Wårvick, B., S.K. Tanskanen and R. Hiltunen (Eds.) Organization in Discourse. Proceedings from the Türkü Conference. (p. 257264). University of Türkü. Anglicana Türküensia. Finland.

Flowerdew, J. (2001) Attitude of journal editors to nonnative speaker contributions. TESOL Quarterly. 35(1), 121-151.

Folman, S., and G. Sarig (1990) Intercultural rhetoric differences in meaning construction. Communication and Cognition. 23(1), 45-92.

Fortanet, I. (1998) Verb usage in academic writing: reporting verbs in economics research articles in English and in Spanish. In L. Lundquist, H. Picht and J. Qvistgaard (Eds). LSP Identity and Interface Research, Knowledge and Society. (p. 231-241) Copenhagen Business School. LSP Center.

Galtung, J. (1985) Struktur, kultur und intellektueller stil. Leviathan. 2, p. 303-338.

Guyon, E., and Guyon A. (1996) Anglais de Spécialité et Plurilinguisme. ASp (Anglais de Spécialité). Vol. 11-14, p. 1-12.

Hobbes, T. (1647). English Works of Thomas Hobbes. Sir William Molesworth. London. J. Bohn.

Hume, D. (1757) Essays, Moral, Political and Literacy. Longmans. Gree and Co. London. Hunston, S. (1993): Professional conflict: disagreement in academic discourse. En M. Baker, G. Francis and E. Tognini-Bonelli (Eds.): Text and Technology: In Honor of John Sinclair (p. 11-133). Amsterdam: John Benjamins Publishing Co. 
Hyland, K. (1996) Writing without conviction? Hedging in science research articles. Applied Linguistics. 17(4), 433-454.

. (2000) Disciplinary Discourses. Social Interactions in Academic Writing. Longman.

. (2001). Humble servants of the discipline? Self-mention in research articles. English for Specific Purposes. 20(3), 207-226.

Johns, A.M., and J. Swales (1998) Past imperfect continuous: reflections on two ESP lives. English for Specific Purposes. 17(1), 15-28.

Kourilova, M. (1996): Interactive function of language in peer reviews of medical paper written by NN users of English. UNESCO-ALSED-LSP Newsletter, 19, 1: 4-21.

Kreutz, H., and A. Harres (1997). Some observations on the distribution and function of hedging in German and English academic writing. In A. Duszak (Ed.) Culture and Styles of Academic Discourse (p. 181-202) Berlin: Mouton de Gruyter.

Kubota, R. (1992) Contrastive rhetoric of Japanese and English: a critical approach. Ph. D Dissertation. Department of Education. University of Toronto.

Leech, G. (1983) Principles of Pragmatics. London: Longman

Liskin-Gasparro, J. E. (2001) Reviewing the reviews: a modest history of policies and practices. The Modern Language Journal. 85(1), 77-91.

Locke, J. (1702) Conduct of the Understanding. Editorial T. Fowler. Oxford. Clarendon Press.

López, G.S. (1982) Article Introductions in Spanish: A Study in comparative Rhetoric. Unpublished Master of Science. Birmingham. UK. The Language Studies Unit. University of Aston.

Martin, J. (1996). Les enjeux du discours scientifique: la stratégie de véridiction. ASp. (Anglais de Spécialité). Vol. 11/14. 13-33.

Martín Vivaldi, G. (2000) Curso de Redacción. Teoría y Práctica de la Composición y del Estilo. Paraninfo. Thomson Learning. Madrid.

Martínez, S. (1994) Spanish English cognates in the sub-technical vocabulary in engineering magazine texts. English for Specific Purposes. 13(1), p. 81-91.

Mauranen, A. (1992) Contrastive ESP rhetoric: metatexts in Finnish-English economics texts. English for Specific Purposes. An International Journal. 12, p. 3-22. 
(1993) Cultural Differences in Academic Rhetoric. Frankfurt am Main:

Peter Lang.

Meyer, P.G. (1997) Hedging strategies in written academic discourse: strengthening the arguments by weakening the claim. In R. Markkanen and H. Schröder (Eds.) Hedging and Discourse. Approaches to the Analysis of a Pragmatic Phenomenon in Academic Texts. (p. 21-41) Mouton de Gruyter. Berlin.

Motchane, J.L. (1990): Chercher, inventer, innover dans la langue. In B. Cassen (Ed.): Quelles langues pour la science? (p. 4-62). Paris: Éditions de la Découverte.

Montolio, E. C, Figueras, M. Garachana and M. Santiago (2000) Manual Práctico de Escritura Académica. Barcelona. Editorial Ariel.

Moreno, A. I. (1997) Genre constraints across languages: causal metatext in Spanish and English RAs. English for Specific Purposes. 16(3), 161-179.

Navarro, F.A. (1998). En pos de la Verdadera Causa de los Anglicismos Médicos. In L. Félix Fernández, E. Ortega and E. Arjonilla (Coords.). II Estudios sobre Traducción e Interpretación: 1079-1091. Málaga: Universidad de Málaga y Centro de Ediciones de la Diputación de Málaga (CEDMA).

Olsen, S. (1999) Errors and compensatory strategies: a study of grammar and vocabulary in texts written by Norwegian learners of English. System. 27(2), p. 191-295.

Pak, C. (1995) Editorials in Mexico, Spain and the USA: A Comparative Rhetorical Analysis. Unpublished Doctoral Dissertation. University of Michigan. Ann Arbor.

Parkhurst, C. (1990) The composition process of science writers. English for Specific Purposes. Vol. 9(2), 169-179.

Régent, O. (1994): L'article scientifique: un produit culturel. ASp (Anglais de Spécialité): Vol. 5/6. p. 55-61.

Salager-Meyer, F. (1999) Contentiousness in medical English written discourse: a diachronic study (1810-1995). TEXT, 19, 3: 371-398.

(2001) 'This book portrays the worst form of mental terrorism': critical speech acts in medical English book reviews. Approaches to the Pragmatics of Scientific Discourse. (p. 47-72) A. Kertész (Ed.) Berlin: Peter Lang

Salager-Meyer, F. and M.A. Alcaraz Ariza (2001): Lo cortés no quita lo valiente: la retórica de la discrepancia en el discurso médico escrito en español (1880-1899). In J. C. 
Palmer; S. Posteguillo, S. and E I. Fortanet (Eds.): Discourse analysis and terminology in Languages for Specific Purposes. (p. 15-24). Col-lecció «Estudis Filològics», 5. Castellón: Publicaciones de la Universitat Jaume I.

Salager-Meyer, F., and N. Zambrano (2001) The bittersweet rhetoric of controversiality in nineteenth- and twentieth-century French and English Medical literature. Journal of Historical Pragmatics, 2, 1: 141-173.

Schiffrin, D. (1994) Approaches to Discourse. Oxford University Press.

Segura, J. (1998): Some Thoughts on the Spanish Language in Medicine. In H. Fischbach (Ed.): Translation and Medicine. (p. 37-48). Amsterdam/Philadelphia: John Benjamins Publishing Co.

Selinker, L. (1979): On the use of specialist informants in discourse analysis and languages for specialized purposes. International Review of Applied Linguistics and Language Teaching, 17: 481-520.

Shaw, P. (1991). Science research students' composing process. English for Specific Purposes.10, 189-206.

Sionis, C. (1997): Writing scientific discourse beyond words. ASp: (Anglais de Spécialité). 15/18: 339-357.

(2000) La démarche pragmatique de définition dans le discours scientifique. Unpublished Seminar.

Sniderman, A.D. (1999) Clinical trials, consensus conferences and clinical practice. The Lancet. 357: 327-30.

St. John, M.J. (1987) Writing processes of Spanish scientists publishing in English. English for Specific Purposes. 6(2), 113-120.

Swales, J. (1990). Genre Analysis. Cambridge: C.U.P.

(2000) Languages for specific purposes. Annual Review of Applied Linguistics. 20, 59-76.

Taavitsainen, I., and P. Pahta (1998) Vernacularisation of medical writing in English: a corpus-based study of scholasticism. Early Science and Medicine. 3(2), 157-187.

Taylor, G., and T.G. Chen (1991) Linguistic, cultural and sub-cultural issues in contrastive discourse analysis: Anglo-American and Chinese scientific texts. Applied Linguistics. 12, 319-336. 
Valero Garcés, C. (1997) Contrastive rhetoric in ESP: a cross-linguistic analysis of finite verb profiles in English and Spanish medical abstracts. UNESCO-ALSED LSP Newsletter. 20(2), 22-36.

Valle, E (1999) A Collective Intelligence: The Life Sciences in the Royal Society as a Scientific Discourse Community (1665-1965). Anglicana Türküensia, 17. Finland: Universidad de Türkü.

Vasquéz, F. (1987) A Comparative Study of the Rhetorical Structure of the Discussion Sections in English and Spanish Medical Abstracts. MSc. Dissertation. Aston University, Birmingham, UK.

Vassileva, I. (1997) Hedging in English and Bulgarian academic writing. In A. Duszak (Ed.) Culture and Style in Academic Discourse. Mouton de Gruyter. Berlin. p. 203221.

(2001) Commitment and detachment in English and Bulgarian academic writing. English for Specific Purposes. 20(1), 83-102.

Ventola, E. (1997) Modalization: probability -- an exploration into its role in academic writing. In A. Duszak. Culture and Styles of Academic Discourse. Trends in Linguistics. Studies and Monograph 104. (p. 157-179). Berlin. Mouton de Gruyter.

Williams, J. (1992) Planning, discourse marking, and the comprehensibility of international teaching assistants. TESOL Quarterly. 26(4), 693-711.

Wilss, W. (1997) Hedging in expert-language reviews. In R. Markkanen and H. Schröder (Eds.) Hedging and Discourse. Approaches to the Analysis of a Pragmatic Phenomenon in Academic Texts. (p. 134-150) Mouton de Gruyter. Berlin.

Yakhontova, I. (2001) “Textbooks, contexts and learners" English for Specific Purposes. (20. Supplement 1), p. 397-415.

Zambrano, N. (1999): Las confrontaciones académicas (CCAA) en el discurso médico escrito en inglés y francés: un estudio diacrónico comparativo (1810-1995). M.A. Thesis. Mérida (Venezuela). Universidad de Los Andes. 


\section{AUTHORS' VITAE}

Françoise Salager-Meyer holds an M.A. in Russian language and literature (University of Lyons, France) and a Ph D in Foreign Language Education (University of Texas at Austin, USA). She is currently teaching ESP (reading and writing), French and Russian at the University of the Andes (Mérida, Venezuela) and has published a number of papers on the linguistic features of medical English.

María Angeles Alcaraz Ariza holds a B.A. in English Studies and a PhD in linguistics. She teaches English phonetics and ESP at the University of Alicante (Spain). She has published several articles on the influence of English on medical Spanish and is conducting research on the discoursal features of medical language.

Nahirana Zambrano holds a BA in English and an M.A. in linguistics from the University of The Andes (Mérida, Venezuela) where she is currently teaching EFL for intermediate and advanced students. 


\section{APPENDIX 1}

\section{JOURNALS FROM WHICH THE SAMPLE TEXTS WERE DRAWN}

\section{Spanish}

Anales de Medicina Interna (AMI)

Medicina Clínica (MC)

Archivos de la Facultad de Medicina de Madrid (AFMM)

Revista Clínica Española (RCE)

\section{French}

Annales de l'Institut Pasteur (AIP)

Académie Nationale de la Médecine (ANM)

Annales de Médecine Interne (AMI)

Journal de Chirurgie et Pratique Médicale Française (JCPMF)

\section{English}

The Journal of the American Medical Association (JAMA)

Annals of Internal Medicine (AIM/1)

Archives of Internal Medicine (AIM/ 2)

The Lancet (L)

The British Medical Journal (BMJ)

The New England Journal of Medicine (NEJM) 


\section{Table 1}

Total number of words and of academic conflicts (AC). Normalizalization of results per 10.000 words

\begin{tabular}{|l|c|c|c|}
\cline { 2 - 4 } \multicolumn{1}{c|}{} & $\mathrm{N}^{\circ}$ Words & $\begin{array}{c}\text { Total AC } \\
\text { recorded }\end{array}$ & $\begin{array}{c}\text { Normalization per } \\
10.000 \text { words }\end{array}$ \\
\hline English & 65,502 & 77 & 11.7 \\
\hline French & 69,817 & 120 & 17.2 \\
\hline Spanish & 82,794 & 144 & 17.4 \\
\hline Total & 218,113 & 341 & \multicolumn{1}{c|}{} \\
\cline { 1 - 3 } & \multicolumn{2}{|c|}{}
\end{tabular}




\section{Table 2}

Total number and percentages of direct and indirect academic conflicts (AC) recorded in the three corpora

\begin{tabular}{|c|c|c|c|}
\hline & $\begin{array}{c}\text { English } \\
1930-1995\end{array}$ & $\begin{array}{c}\text { French } \\
1930-1995\end{array}$ & $\begin{array}{c}\text { Spanish } \\
1930-1995\end{array}$ \\
\hline & 44 & $104 \quad p=.0001$ & 114 \\
\hline Direct AC & $57.1 \%$ & $\begin{array}{c}86.70 \% \\
\text { 个๐ } \\
8\end{array}$ & $\begin{array}{r}79.2 \% \\
\text { 个ठ } \\
\end{array}$ \\
\hline Indirect AC & $42.8 \%$ & 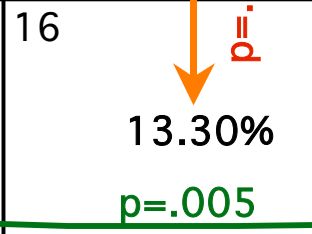 & 30 \\
\hline TOTAL & 77 & 120 & 144 \\
\hline
\end{tabular}




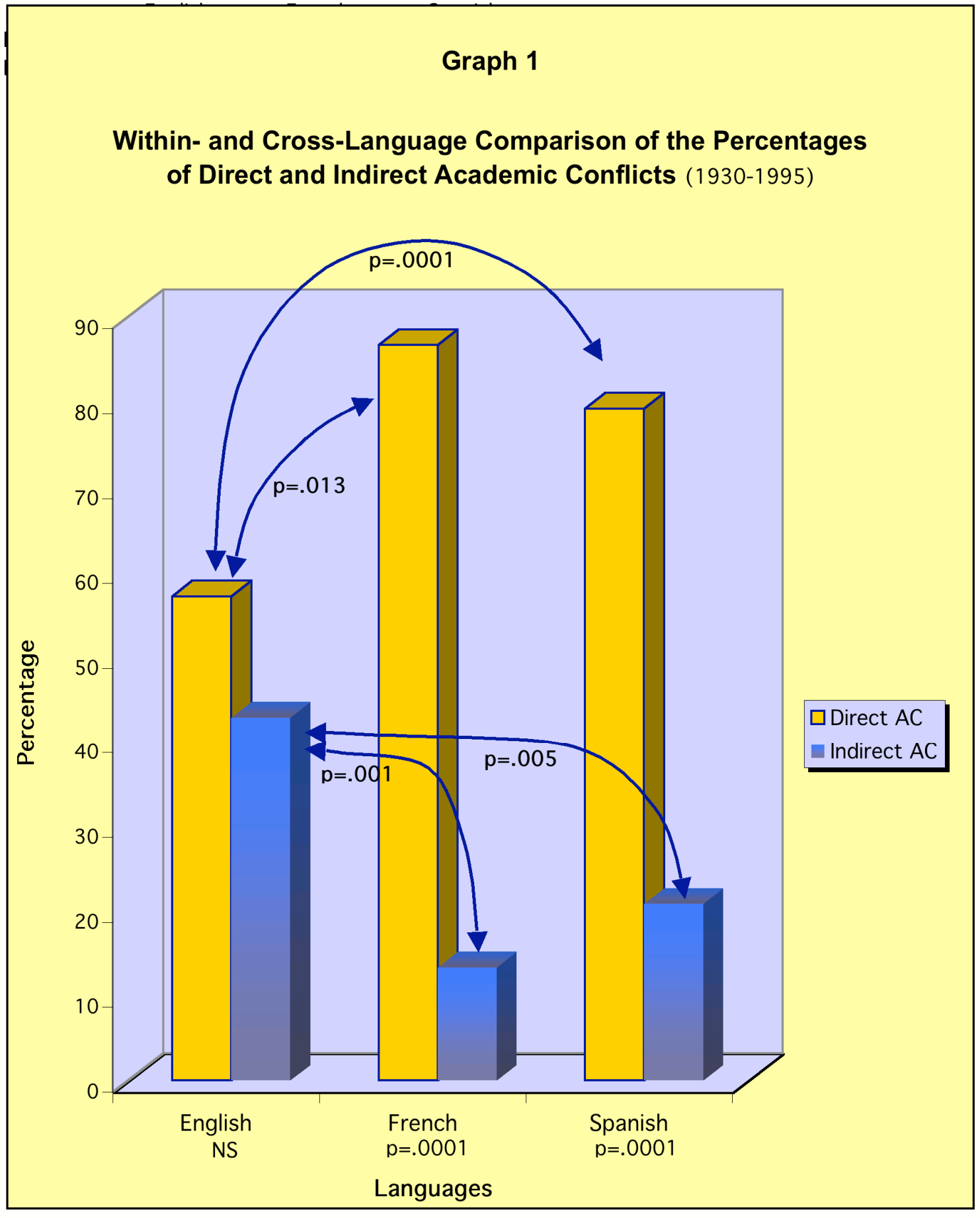




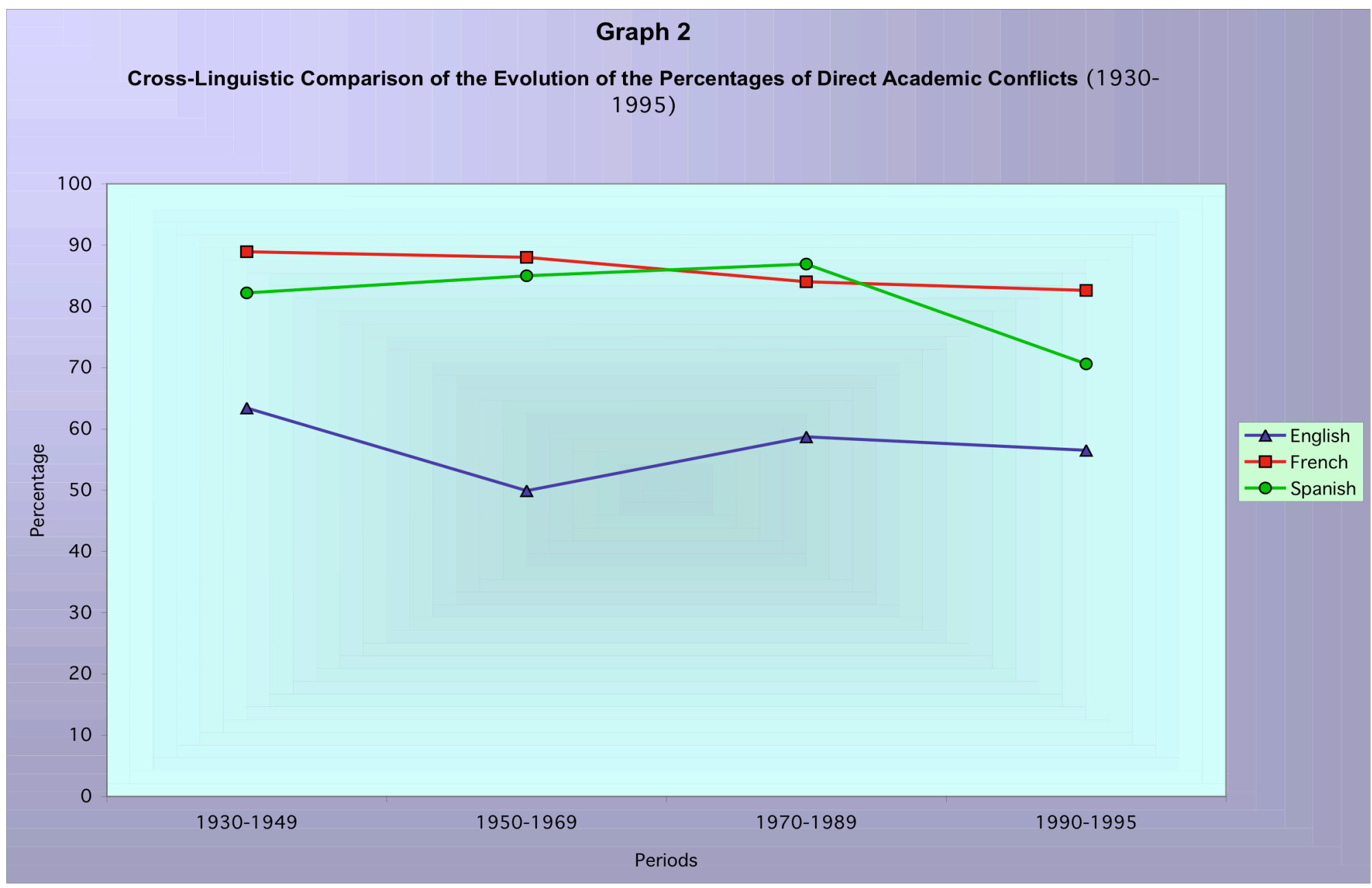




\section{Graph 3}

Cross-Linguistic Comparison of the Evolution of Indirect Academic Conflicts (1930-1995)

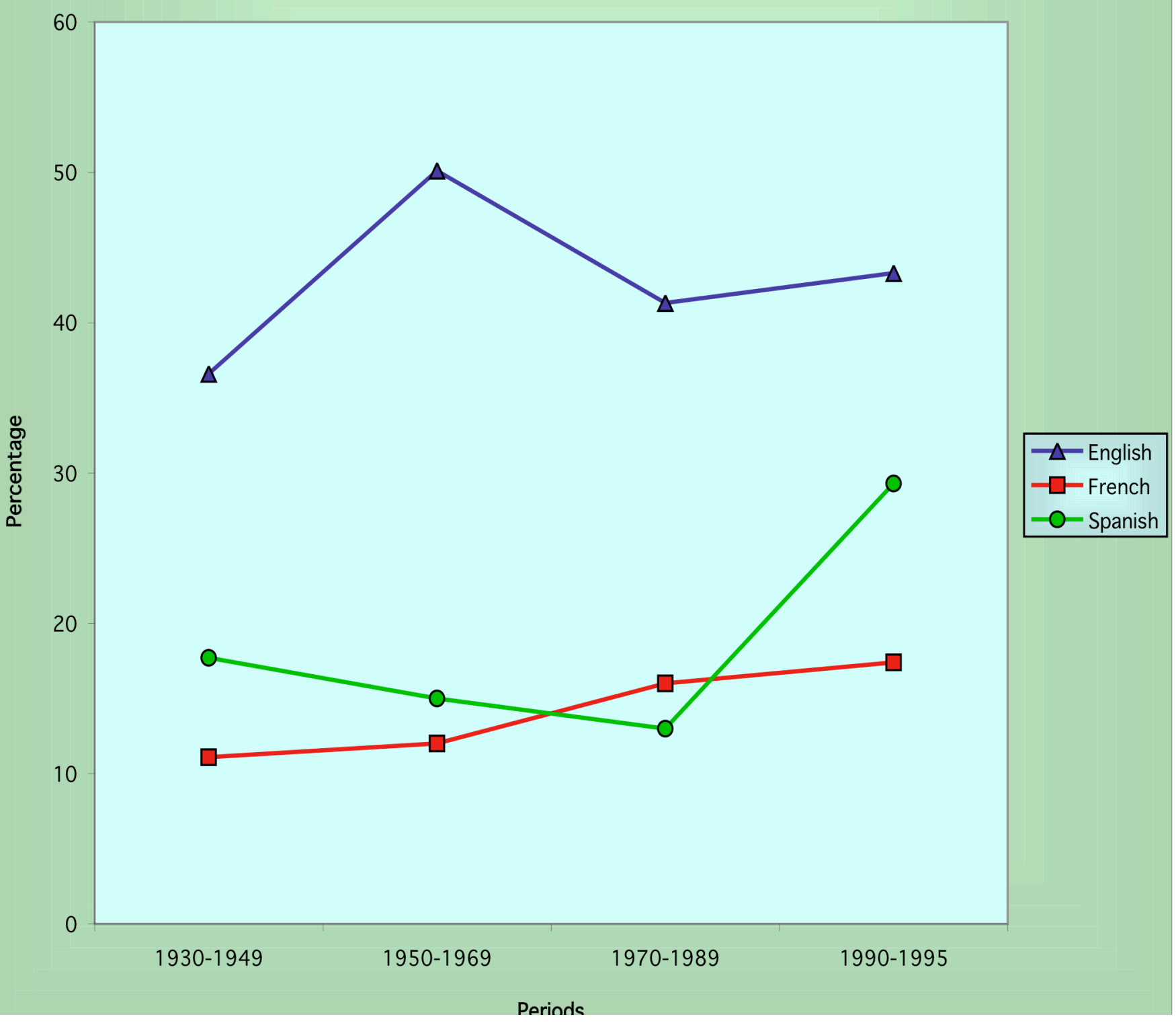


